\title{
PENGARUH PRODUCT MIX PRICING STRATEGY TERHADAP KEPUTUSAN MENGINAP DI ANGGREK SHOPPING HOTEL BANDUNG (Survei Terhadap Tamu Individu yang Menginap di Anggrek Shopping Hotel Bandung)
}

\author{
Riane Rahayu \\ Dewi Pancawati Novalita \\ Manajemen Pemasaran Pariwisata FPIPS UPI
}

\begin{abstract}
There are shopping hotel in Bandung, which are Hyatt Regency Hotel, Sensa Hotel, Aston Braga Hotel \& Apartement, Harris Hotel, BTC Hotel and Anggrek Shopping Hotel. Anggrek Shopping Hotel is one of the hotel with two stars classification which is located in heart of the city of Bandung in Martadinata street number 15 where is connecting directly with Riau Junction shopping mall with only 41 rooms and better service than before. Over last two years with new mangement, Anggrek Shopping Hotel is still has fluctuatif occupancy, so that in third years internal management make a new strategy on product and pricing for the guest. The responden of this research is individuals guest who stay in Anggrek Shopping Hotel Bandung. This research was conducted for two months, from September 2012 until October 2012. This type of study is a descriptive and verifikatif, and for method are using survey explanatory method ans simple random sampling technique, and for number of samples to be studies were 100 respondens. The data analysis technique is regression with SPSS 17.0 as the computer software. The data collection technique are interviews and questionnaire distribution. The finding of this research is there an impact of product mix pricing strategy which consists of product line pricing, optional product pricing, and product bundle pricing. On decision to stay. The dimension of product mix pricing strategy which has the highest influence is product bundle pricing and the one with lowest influence is product line pricing. While the most appealing factor of decision to stay is product and service. Suggestion to Anggrek Shopping Hotel Bandung is about internal facilities to increase the interest to stay in Anggrek Shopping Hotel Bandung.
\end{abstract}

Keyword : Product Mix Pricing Strategy, Decision to Buying, Anggrek Shopping Hotel Bandung.

\section{PENDAHULUAN}

\subsection{Latar Belakang}

Indonesia memiliki berbagai jenis pariwisata yang dapat menarik wisatawan khususnya wisatawan mancanegara agar tertarik untuk berkunjung, ini yang menjadi salah satu alasan utama mengapa pertumbuhan hotel di Indonesia diprediksi signifikan. Berikut Tabel 1.1 merupakan data kunjungan wisatawan mancanegara ke Indonesia tahun 2010-2011.

\section{TABEL 1.1}

DATA KUNJUNGAN WISATAWAN MANCANEGARA KE INDONESIA PADA TAHUN 2009-2011

\begin{tabular}{|c|c|}
\hline Tahun & Jumlah Kunjungan Wisatawan \\
\hline 2009 & 6.323 .730 orang \\
\hline 2010 & 7.002 .944 orang \\
\hline 2011 & 7.649.731 orang \\
\hline
\end{tabular}


Tabel 1.1 menunjukkan bahwa tingkat kunjungan wisatawan mancanegara ke Indonesia mengalami peningkatan selama tiga tahun terakhir. Tercatat kenaikan jumlah wisatawan dari tahun 2009 ke 2010 sebesar $10,74 \%$, dan ditahun selanjutnya kenaikan sebesar $8,54 \%$.

Pariwisata juga merupakan salah satu faktor penting dalam perkembangan perekonomian di Jawa Barat, salah satunya pariwisata dalam bidang akomodasi perhotelan. Jawa Barat memiliki berbagai destinasi pariwisata yang tak kalah menarik dengan provinsi-provinsi lain yang tersebar di seluruh kawasan Indonesia. Hal ini berpengaruh terhadap tingkat penghunian kamar selama dua tahun terakhir, pernyataan tersebut dipertegas dalam Tabel 1.2 berikut.

TABEL 1.2

TINGKAT PENGHUNIAN KAMAR DI JAWA BARAT TAHUN 2011-2012

\begin{tabular}{|c|c|c|}
\hline Bulan & Tahun 2011 & Tahun 2012 \\
\hline Januari & $48,40 \%$ & $50,15 \%$ \\
\hline Februari & $48,74 \%$ & $49,10 \%$ \\
\hline Maret & $48,91 \%$ & $49,17 \%$ \\
\hline April & $49,57 \%$ & $48,37 \%$ \\
\hline Mei & $49,76 \%$ & $49,79 \%$ \\
\hline Juni & $52,93 \%$ & $56,19 \%$ \\
\hline Juli & $59,59 \%$ & $47,85 \%$ \\
\hline Agustus & $38,57 \%$ & $39,29 \%$ \\
\hline September & $35,68 \%$ & Belum diketahui \\
\hline Oktober & $48,51 \%$ & Belum diketahui \\
\hline November & $43,68 \%$ & Belum diketahui \\
\hline Desember & $48,67 \%$ & Belum diketahui \\
\hline
\end{tabular}

Sumber: Badan Pusat Statistik 2012

Berdasarkan Tabel 1.2 bahwa tingkat penghunian kamar di Jawa Barat pada dua tahun terakhir mengalami fluktuasi.

Pemerintah Kota Bandung hanya mengandalkan pemasukan dari pajak hotel, restoran, dan hiburan. Meski demikian hal ini merupakan suatu daya tarik wisatawan mancanegara dan domestik untuk melakukan kunjungan ke Kota Bandung dengan berbagai tujuan salah satunya untuk berbelanja. Berikut Tabel 1.3 merupakan data wisatawan yang menginap di Kota Bandung pada tahun 2009-2011.

TABEL 1.3

DATA WISATAWAN YANG MENGINAP DI KOTA BANDUNG

\begin{tabular}{|c|c|c|c|}
\hline & Jumlah Tahun & Jumlah Tahun & Jumlah Tahun \\
Asal Wisatawan & $\mathbf{2 0 0 9}$ & $\mathbf{2 0 1 0}$ & $\mathbf{2 0 1 1}$ \\
\hline Wisatawan Nusantara & 7.515 .269 & 4.951 .439 & 6.487 .239 \\
\hline Wisatawan Mancanegara & 70.175 & 228.449 & 225.585 \\
\hline Total & $\mathbf{7 . 5 8 5 . 4 4 4}$ & $\mathbf{5 . 1 7 9 . 8 8 8}$ & $\mathbf{6 . 7 1 3 . 3 2 4}$ \\
\hline
\end{tabular}

Sumber: Dinas Kebudayaan Pariwisata Kota Bandung, 27 Januari 2012

Tabel 1.3 menunjukan bahwa terjadi fluktuasi selama tiga tahun terakhir. Penurunan terjadi pada tahun 2010 yaitu sebesar 2.405.556 orang atau sekitar 31,71\% dari jumlah wisatawan pada tahun 2009. Peningkatan jumlah wisatawan kembali terjadi pada tahun 2011 yaitu sebesar 1.533.436 orang atau sekitar $29,60 \%$ dari jumlah wisatawan tahun sebelumnya.
Hotel adalah sarana tempat tinggal umum untuk wisatawan dengan syarat pembayaran serta memberikan pelayanan makanan dan akomodasi. Dilihat dari fungsi utamanya, produk utama yang dijual oleh usaha perhotelan adalah sewa kamar atau jasa penginapan. Sejalan dengan perkembangan tersebut, maka jika sebelumnya produk dan jasa utama sebuah hotel yang menjadi kebutuhan utama 
wisatawan adalah kamar atau penginapan sekarang sudah mengalami perkembangan. Konsumen mengharapkan sesuatu yang bukan hanya sekedar kamar menginap, namun mereka lebih mengharapkan hal lain seperti kondisi lingkungan yang menyenangkan, sopan santun dan rasa hormat dari seluruh karyawannya. Sejalan dengan perkembangan dunia perhotelan di kawasan Kota Bandung yang semakin pesat, maka muncullah ide-ide untuk membangun industri perhotelan ditengah-tengah shopping mall dan kawasan wisata belanja yang berada di Kota Bandung. Berikut Tabel 1.4 merupakan hotel-hotel di Kota Bandung yang berdiri ditengah-tengah shopping mall dan kawasan wisata belanja di Kota Bandung.

TABEL 1.4

HOTEL BERKONSEP SHOPPING MALL DI KOTA BANDUNG

\begin{tabular}{|c|c|c|c|}
\hline No & Nama Hotel & Jangkauan Wisata Belanja & Lokasi \\
\hline 1. & Hyatt Regency & $\begin{array}{c}\text { Bandung Indah Plaza, Jalan Riau, } \\
\text { Jalan Merdeka }\end{array}$ & Jalan Sumatera \\
\hline 2. & Sensa Hotel & $\begin{array}{c}\text { Cihampelas Walk, wisata belanja } \\
\text { di sepanjang jalan Cihampelas, } \\
\text { Jalan Setiabudhi }\end{array}$ & Jalan Cihampelas \\
\hline 3. & Anggrek Shopping Hotel & $\begin{array}{c}\text { Riau Junction, Jalan Riau, Jalan } \\
\text { Merdeka }\end{array}$ & Jalan Riau \\
\hline 4. & Aston Braga Service Apartement & $\begin{array}{c}\text { Braga City Walk, Alun-alun } \\
\text { Bandung }\end{array}$ & Jalan Braga \\
\hline
\end{tabular}

Sumber: Dinas Kebudayaan Pariwisata Kota Bandung 2011

Tabel 1.4 menunjukkan bahwa terdapat beberapa hotel dengan klasifikasi bintang berbeda-beda yang berdiri ditengah-tengah shopping mall dan beberapa titik besar kawasan wisata belanja di Kota Bandung. Keempat hotel tersebut juga merupakan hotel yang berkonsep hotel dan mall atau shopping hotel karena letaknya yang berkoneksi langsung dengan shopping mall. Tabel 1.5 berikut akan menunjukkan tingkat room occupancy selama dua tahun terakhir dari hotel yang yang berkonsep shopping hotel dan yang letaknya berada di kawasan wisata belanja di Kota Bandung.

TABEL 1.5

ROOM OCCUPANCY HOTEL

BERKONSEP SHOPPING MALL DI KOTA BANDUNG TAHUN 2010-2011

\begin{tabular}{|c|l|c|c|}
\hline \multirow{2}{*}{ No } & \multicolumn{2}{|c|}{ Hotel } & \multicolumn{2}{c|}{ Room Occupancy } \\
\cline { 3 - 4 } & & $\mathbf{2 0 1 0}$ & $\mathbf{2 0 1 1}$ \\
\hline 1 & Hyatt Regency Hotel & $78 \%$ & $82 \%$ \\
\hline 2 & Sensa Hotel & $60.72 \%$ & $80.99 \%$ \\
\hline $\mathbf{3}$ & Anggrek Shopping Hotel & $\mathbf{7 1 , 5 1 \%}$ & $\mathbf{6 9 , 3 8 \%}$ \\
\hline 4 & Aston Braga Service Apartement & $65,65 \%$ & $72,65 \%$ \\
\hline
\end{tabular}

Sumber: Data olahan dari tiap-tiap manajemen hotel, Februari 2012

Tabel 1.5 menunjukkan bahwa room occupancy tertinggi selama dua tahun terakhir dipegang oleh hotel Hyatt Regency yang terletak di Jl.Sumatera, diikuti Sensa hotel yang terletak di Jl.Cihampelas, peringkat ketiga terdapat pada Aston Braga Service Apartement yang terletak di Jl.Braga, dan posisi terbawah terdapat di
Anggrek Shopping Hotel Bandung yang terletak di Jl. LL.RE Martadinata.

Kamar hotel merupakan produk utama dalam sebuah perusahaan akomodasi perhotelan, jika selalu terjadi penurunan tingkat hunian kamar pada setiap tahunnya, tentu akan sangat berdampak negatif pada perusahaan akomodasi tersebut. Hal ini yang 
terjadi pada Anggrek Shopping Hotel Bandung dalam dua tahun terakhir. Jika selalu mengalami penurunan dalam penjualan produk utama, maka akan banyak mendapatkan dampak negatif. Salah satu dampak negatif yang sangat fatal berdampak pada sistem keuangan yang dikelola oleh pihak hotel dan sumber daya manusia yang terdapat di dalam Anggrek Shopping Hotel Bandung tersebut. Jika penurunan tingkat hunian kamar terus terjadi, akan mengurangi pemasukan keuangan pada pihak manajemen perusahaan, sedangkan sumber daya manusia di dalamnya harus tetap diperhatikan upah setiap bulannya seperti yang sudah ditetapkan dalam perjanjian kontrak kerja antara kedua belah pihak sebelumnya. Hal seperti itu merupakan satu dari beberapa dampak negatif yang kemungkinan dapat terjadi. Maka perlu dilakukan upaya untuk dapat memperbaiki tingkat hunian kamar agar terus meningkat setiap bulan dan tahunnya.

Dilakukan upaya semaksimal mungkin untuk dapat mengetahui seberapa besar pengaruh keputusan menginap pada Anggrek Shopping Hotel Bandung, tentunya upaya yang tidak mengeluarkan biaya yang terlalu banyak. Melakukan berbagai macam strategi place, shopping tourism, strategi media promosi seperti selalu memberi informasi terbaru mengenai produk-produk dan promosi yang dilakukan oleh pihak internal hotel, serta product mix pricing strategy seperti penetapan harga pada setiap produk yang terdapat di Anggrek Shopping Hotel, serta melakukan program dari product mix pricing tersebut seperti pembagian voucher belanja gratis di Riau Junction bagi para tamu yang menginap di Anggrek Shopping Hotel Bandung minimal selama dua malam, yang diharapkan para tamu akan terus tertarik untuk menginap di Anggrek Shopping Hotel Bandung, karena antara Anggrek Shopping Hotel dan Riau Junction berada dalam badan hukum yang sama yaitu PT. Akur Pratama.

Salah satu strategi yang akan diteliti oleh penulis terhadap Anggrek Shopping Hotel Bandung yaitu strategi yang berfokus pada product mix pricing strategy, untuk mempengaruhi kepada keputusan menginap tamu individu di Anggrek Shopping Hotel Bandung. Penetapan harga dengan membaurkan beberapa produk menjadi satu harga dapat sangat menunjang pelaksanaan product mix pricing strategy tersebut. Diharapkan product mix pricing strategy dapat meningkatkan keputusan menginap tamu di Anggrek Shopping Hotel Bandung.

Adapun strategi dan program yang diaplikasikan oleh pihak Anggrek Shopping Hotel Bandung dari strategi product mix pricing strategy ini tertuang dalam Tabel 1.6 berikut:

TABEL 1.6

PRODUCT MIX PRICING STRATEGY YANG DILAKUKAN

DI ANGGREK SHOPPING HOTEL BANDUNG PADA TAHUN 2012

\begin{tabular}{|c|c|}
\hline Jenis Strategi & Aplikasi \\
\hline $\begin{array}{c}\text { Product Line Pricing } \\
\text { (strategi jangka panjang) }\end{array}$ & $\begin{array}{l}\text { - Penetapan harga dari tiap-tiap tipe kamar } \\
\text { yang ditawarkan di Anggrek Shopping } \\
\text { Hotel Bandung } \\
\text { - Penetapan harga dari tiap-tiap jenis } \\
\text { makanan yang ditawarkan di restoran } \\
\text { Anggrek Shopping Hotel Bandung } \\
\text { - Penetapan harga dari tiap-tiap jenis } \\
\text { minuman yang ditawarkan di restoran } \\
\text { Anggrek Shopping Hotel Bandung }\end{array}$ \\
\hline $\begin{array}{l}\text { Optional Product Pricing } \\
\text { (strategi jangka panjang) }\end{array}$ & $\begin{array}{l}\text { - Penetapan harga extra bed yang ditawarkan } \\
\text { di Anggrek Shopping Hotel Bandung } \\
\text { - Penetapan harga binatu/laundry yang }\end{array}$ \\
\hline
\end{tabular}




\begin{tabular}{|c|c|}
\hline & $\begin{array}{l}\text { ditawarkan di Anggrek Shopping Hotel } \\
\text { Bandung } \\
\text { - Harga outgoing call yang ditawarkan di } \\
\text { Anggrek Shopping Hotel Bandung } \\
\text { - Harga fasilitas bussiness center yang } \\
\text { ditawarkan di Anggrek Shopping Hotel } \\
\text { Bandung }\end{array}$ \\
\hline $\begin{array}{c}\text { Product Bundle Pricing } \\
\text { Program } \\
\text { (Periode Juni 2012 - Agustus 2012) }\end{array}$ & $\begin{array}{l}\text { - Harga meeting package yang ditawarkan di } \\
\text { Anggrek Shopping Hotel Bandung } \\
\text { - Penetapan harga paket } 2 \text { malam kamar } \\
\text { dengan } 1 \text { voucher belanja di Riau Junction } \\
\text { senilai Rp. 150.000,- } \\
\text { - Penetapan harga paket varian kopi dengan } \\
\text { varian snack yang dijual senilai Rp. } \\
\text { 20.000++ }\end{array}$ \\
\hline
\end{tabular}

Tabel 1.6 menjelaskan bahwa terdapat aplikasi dari product mix pricing strategy yang digunakan oleh pihak manajemen Anggrek Shopping Hotel Bandung, yang antara lainnya penetapan harga dari seluruh lini produk, penetapan harga dari produk pendukung yang terdapat di Anggrek Shopping Hotel Bandung, dan program penetapan harga dari produk yang sudah dipaketkan dan dijual dalam satu harga saja.

Berdasarkan uraian diatas maka perlu untuk dilakukannya penelitian mengenai "Pengaruh Product Mix Pricing Strategy Terhadap Keputusan Menginap di Anggrek Shopping Hotel Bandung (Survei Terhadap Tamu Individu yang Menginap di Anggrek Shopping Hotel Bandung)".

\subsection{Rumusan Masalah}

Berdasarkan uraian tersebut, maka dapat dirumuskan beberapa masalah untuk memperoleh penelitian sebagai berikut.

1. Bagaimana product mix pricing strategy diterapkan pada salah satu strategi dari pihak internal Anggrek Shopping Hotel Bandung.

2. Bagaimana gambaran tingkat keputusan menginap pada Anggrek Shopping Hotel Bandung.

3. Bagaimana pengaruh product mix pricing strategy terhadap tingkat keputusan menginap di Anggrek Shopping Hotel.

\subsection{Tujuan Penelitian}

Penelitian ini dimaksudkan untuk mengungkapkan data dan informasi yang berhubungan dengan pengaruh product mix pricing strategy terhadap tingkat keputusan menginap di Anggrek Shopping Hotel:

1. Memperoleh temuan hasil dari aplikasi product mix pricing strategy yang dilakukan oleh pihak internal Anggrek Shopping Hotel Bandung.

2. Memperoleh temuan gambaran tingkat keputusan menginap tamu di Anggrek Shopping Hotel Bandung.

3. Memperoleh temuan mengenai pengaruh product mix pricing strategy terhadap keputusan menginap tamu di Anggrek Shopping Hotel Bandung.

\subsection{Kegunaan Penelitian}

Adapun manfaat dari penelitian ini adalah :

1. Secara praktis, hasil penelitian ini diharapkan akan memperluas wawasan kajian ilmu mengenai kepariwisataan di program studi Manajemen Pemasaran Pariwisata khususnya pada manajemen pemasaran hotel, serta dapat 
memberikan saran bagi peneliti dalam mengembangkan kajian mengenai ilmu pemasaran khususnya mengenai teori pengaruh product mix pricing strategy terhadap keputusan menginap tamu di Anggrek Shopping Hotel Bandung.

2. Secara teoritis, hasil penelitian ini diharapkan dapat memberikan masukan bagi industri perhotelan berkonsep shopping hotel, khususnya bagi Anggrek Shopping Hotel Bandung dalam melaksanakan product mix pricing strategy dengan sebaik-baiknya untuk mempengaruhi keputusan menginap tamu ,sehingga dapat mencapai tujuan perusahaan yaitu meningkatkan tingkat kunjungan wisata ke Kota Bandung.

\section{KAJIAN PUSTAKA}

\subsection{Kerangkan Pemikiran}

Marketing Mix Strategy adalah suatu rencana tindakan untuk menganalisis target pasar dengan menggunakan alat bauran pemasaran tradisional yang biasa disebut dengan 4P's yaitu product, price, place and promotion guna mengetahui kebutuhan dan keinginan dari target pasar.

Strategi bauran pemasaran tradisional terdiri dari empat komponen utama, salah satunya adalah stategi harga. Strategi harga merupakan strategi khusus yang digunakan untuk menentukan harga barang dan jasa, yang tumbuh dari strategi pemasaran untuk merumuskan tujuan dari organisasi suatu perusahaan secara keseluruhan, yang mana strategi harga terdiri dari lima jenis, yaitu : (1) new product pricing strategy, (2) product mix pricing strategy, (3) price adjustment strategy, (4) price changes, (5) public policy and marketing.
Product mix pricing merupakan strategi harga untuk mengatur harga produk yang sering berubah ketika suatu produk berada dalam produk campuran seperti harga paket. Product mix pricing strategy ini memiliki strategi-strategi lagi didalamnya. Strategi yang termasuk di dalam product mix pricing strategy itu adalah (1) product Line Pricing, (2) Optional Product Pricing, (3) Captive Product Pricing, (4) By-Product Pricing, dan (5) Product Bundle Pricing.

Product mix pricing strategy yang dilakukan secara efektif akan meningkatkan penjualan dan dapat merangsang keputusan menginap secara langsung. Product mix pricing strategy dapat merubah produk dan jasa di hotel lebih menarik lagi. Product mix pricing strategy merupakan strategi yang sudah banyak digunakan oleh perusahaan akomodasi perhotelan guna untuk menarik perhatian para tamu atau pelanggannya. Product mix pricing strategy merupakan salah satu alat dari strategi yang efektif yang dapat dilakukan oleh pemasar untuk mempengaruhi keputusan menginap tamu hotel. Pengaruh product mix pricing strategy terhadap keputusan menginap bahwa untuk mempengaruhi perasaan yang membuat timbulnya perilaku menginap dan artinya perilaku tamu untuk menginap di suatu hotel, yang mana terdapat tiga dimensi dari lima dimensi product mix pricing strategy yang diaplikasikan oleh pihak manajemen Anggrek Shopping Hotel Bandung, yaitu (1) product Line Pricing, (2) Optional Product Pricing, dan (3) Product Bundle Pricing. Berdasarkan pada uraian di atas, maka kerangka logika yang dikembangkan guna merumuskan permasalahan tersebut dilakukan dengan pendekatan skematis seperti Gambar 2 berikut ini: 


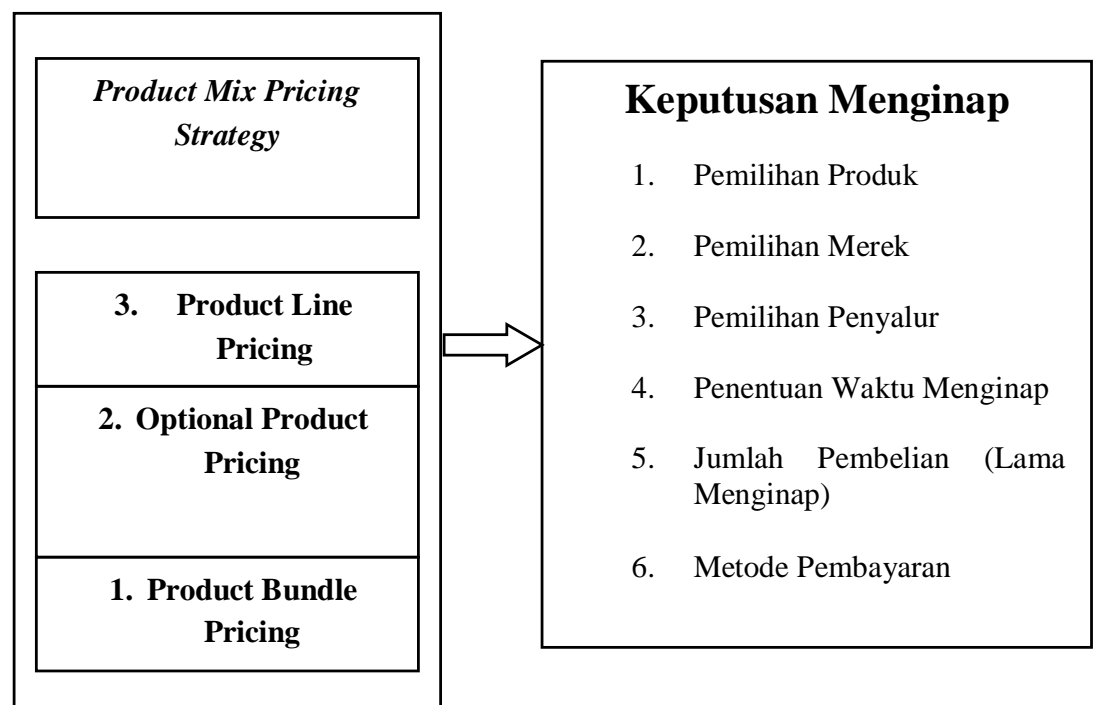

GAMBAR 2

PARADIGMA PEMIKIRAN

\subsection{Hipotesis Penelitian}

Hipotesis sangat berguna dalam penelitian, tanpa antisipasi terhadap alam ataupun tanpa hipotesis, tidak akan ada kelanjutannya dalam wawasan atau pengertian ilmiah dalam mengumpulkan data empirik.

Peneliti dalam menyusun hipotesis di dukung oleh beberapa premis sebagai berikut :

1. Jinhoo Kim dan David C Bonajic (2008)

The result of this study provide a good starting point for understanding the pricing bundling strategy and tactics employed by online travel agents. And in this study is explaning there is pricing strategy has an impact to customer buyer behavior in hotel industry by pricing strategy from travel agent. Berdasarkan hasil pengujian, penelitian ini menyatakan bahwa terdapat pengaruh yang positif antara pricing bundling strategy terhadap keputusan pembelian di industri perhotelan.

2. Etienne Musonera (2005:15)

Product mix pricing strategy in the international hotel requires a shrewd of market strategy and companies need to define their pricing strategy, know their products and understand host country's enviromental factors that can influence to the decision to buying. Product mix pricing strategy dapat mempengaruhi kepada keputusan menginap tamu di suatu hotel.

3. Cathy A Enz, Linda Canina \& Mark Lomanno (2009)

An evaluation of optional pricing and the impact of price change would require models of supply, demand and profitability, including cost . This strategy has strength to make so many people think to buy the product. In this study, the mean of products are everything sells in hotel. Terdapat hubungan yang signifikan antara optional pricing strategy yang merupakan salah satu dimensi dari product mix pricing strategy terhadap keputusan pembelian di suatu hotel.

Berdasarkan premis diatas, maka hipotesis dalam penelitian ini adalah : Terdapat pengaruh yang signifikan antara product mix pricing strategy terhadap keputusan menginap di Anggrek Shopping Hotel Bandung (didukung oleh premis nomor 1 sampai 3). 


\section{METODE PENELITIAN}

\subsection{Objek Penelitian}

Penelitian ini menganalisis mengenai pengaruh product mix pricing strategy terhadap keputusan menginap di Anggrek Shopping Hotel Bandung. Adapun yang menjadi variabel bebas (independent variable) adalah product mix pricing strategy atau variabel $\mathrm{X}$, yang terdiri dari tiga dimensi yaitu product line pricing, optional product pricing dan product bundle pricing. Objek pada variabel terikat (dependent variable) atau variabel $\mathrm{Y}$ adalah keputusan menginap. Penelitian ini dilakukan kepada tamu individu yang menginap di Anggrek Shopping Hotel Bandung dalam waktu kurang dari satu tahun, yaitu mulai Mei 2012 hingga Agustus 2012, oleh karena itu metode pengembangan yang digunakan adalah Cross Sectional Method. Cross Sectional Method menurut Husein Umar (2010:131) adalah metode penelitian dengan cara mempelajari objak dalam satu kurun waktu tertentu/tidak berkesinambungan dalam jangka waktu panjang.

\subsection{Metode Penelitian}

\subsubsection{Jenis dan Metode yang Digunakan}

Sugiyono (2010:35) mendefinisikan bahwa penelitian deskritif adalah penelitian yang dilakukan untuk mengetahui keberadaan varriabel mandiri, baik satu variabel atau lebih variabel (vwriabel yang berdiri sendiri) tanpa membuat perbandingan dan atau mencari hubungan variabel satu sama lain.

Penelitian verifikatif adalah penelitian yang membandingkan keberadaan satu variabel atau lebih pada dua atau lebih sampel yang berbeda, atau pada waktu yang berbeda. Jenis penelitian verifikatif menguji kebenaran suatu hipotesis yang dilakukan melalui pengumpulan data lapangan, dalam hal ini penelitian verifikatif bertujuan untuk mengetahui pengaruh product mix pricing strategy terhadap keputusan menginap di Anggrek Shopping Hotel Bandung.

Berdasarkan jenis penelitian di atas yaitu penelitian deskriptif dan verifikatif yang dilaksanakan melalui pengumpulan data di lapangan, maka metode yang digunakan dalam penelitian ini adalah eksplanatory survey. Menurut Keplinger yang dikutip dalam buku Sugiyono (2010:75) yang dimaksud dengan metode survei yaitu:

Metode penelitian yang dilakukan pada populasi besar maupun kecil, tetapi data yang dielajari adalah data-data dari sampel yang diambil dari populasi tersebut, sehingga ditemukan kejadian-kejadian relatif, distributif, dan hubungan-hubungan antara variabel sosiologis maupun psikologis.

\subsubsection{Operasionalisasi Variabel}

Penelitian ini meliputi dua variabel, yaitu variabel bebas dan variabel terikat. Variabel yang diteliti dalam penulisan ini yaitu pengaruh product mix pricing strategy (X) sebagai variabel bebas dengan dimensi product line pricing, optional product pricing, dan product bundle pricing, sedangkan variabel terikat (Y) adalah keputusan menginap. 
TABEL 3.1

OPERASIONALISASI VARIABEL PENELITIAN

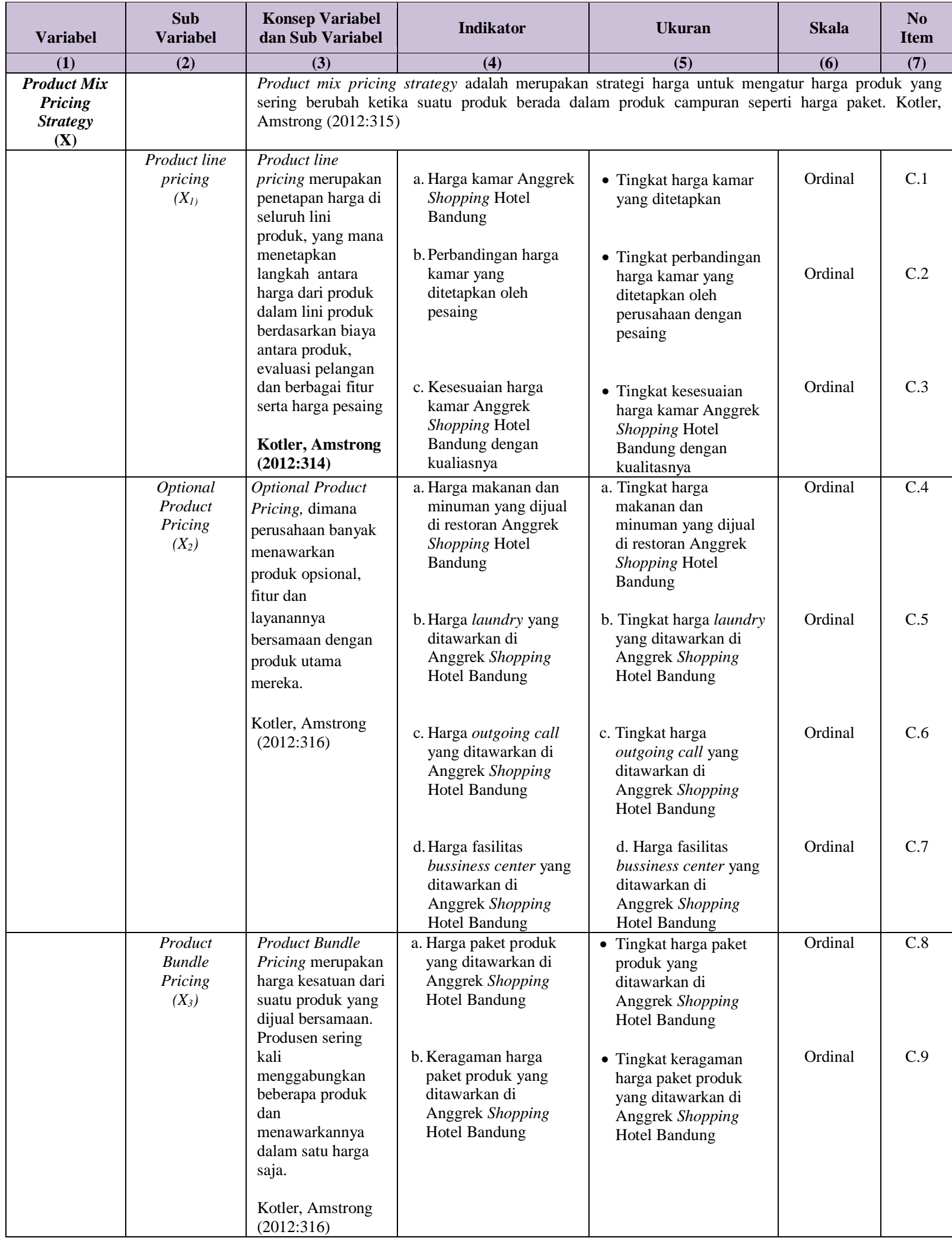

Dilanjutkan 


\begin{tabular}{|c|c|c|c|c|c|c|}
\hline Variabel & $\begin{array}{l}\text { Sub } \\
\text { Variabel }\end{array}$ & $\begin{array}{l}\text { Konsep Variabel } \\
\text { dan Sub Variabel }\end{array}$ & Indikator & Ukuran & Skala & $\begin{array}{l}\text { No } \\
\text { Item }\end{array}$ \\
\hline (1) & (2) & (3) & (4) & (5) & (6) & (7) \\
\hline \multirow[t]{9}{*}{$\begin{array}{l}\text { Keputusan } \\
\text { Menginap } \\
\text { (Y) }\end{array}$} & \multicolumn{6}{|c|}{$\begin{array}{l}\text { Keputusan menginap merupakan proses keputusan di mana tamu atau pelanggan benar-benar memutuskan } \\
\text { menginap dan menikmati produk/jasa diantara berbagai macam alternatif pilihan. Kotler \& Amstrong }(2012: 133)\end{array}$} \\
\hline & $\begin{array}{c}\text { Keputusan } \\
\text { menginap } \\
\text { berdasarkan } \\
\text { produk/jasa }\end{array}$ & & $\begin{array}{l}\text { - Daya tarik produk dan } \\
\text { jasa yang ditawarkan } \\
\text { di Shopping Hotel } \\
\text { yang terdapat di } \\
\text { Bandung } \\
\text { - Keunggulan dari } \\
\text { Shopping Hotel yang } \\
\text { terdapat di Kota } \\
\text { Bandung (seperti } \\
\text { lokasi yang strategis } \\
\text { dengan tempat } \\
\text { perbelanjaan) }\end{array}$ & $\begin{array}{l}\text { - Tingkat daya tarik } \\
\text { produk dan jasa yang } \\
\text { ditawarkan di } \\
\text { Shopping Hotel yang } \\
\text { terdapat di Bandung } \\
\text { - Tingkat keunggulan } \\
\text { dari Shopping Hotel } \\
\text { yang terdapat di Kota } \\
\text { Bandung (seperti } \\
\text { lokasinya yang } \\
\text { strategis dengan temat } \\
\text { perbelanjaan) }\end{array}$ & Ordinal & D.1 \\
\hline & $\begin{array}{c}\text { Keputusan } \\
\text { menginap } \\
\text { berdasarkan } \\
\text { brand (merek) }\end{array}$ & & $\begin{array}{l}\text { - Keunggulan dari } \\
\text { Anggrek Shopping } \\
\text { Hotel Bandung yang } \\
\text { berkoneksi langsung } \\
\text { dengan shopping mall } \\
\text { Riau Junction } \\
\\
\text { - Citra dari Anggrek } \\
\text { Shopping Hotel }\end{array}$ & $\begin{array}{l}\text { - Tingkat keunggulan } \\
\text { dari Anggrek } \\
\text { Shopping Hotel } \\
\text { Bandung yang } \\
\text { berkoneksi langsung } \\
\text { dengan shopping mall } \\
\text { Riau Junction } \\
\text { - Tingkat citra dari } \\
\text { Anggrek Shopping } \\
\text { Hotel } \\
\end{array}$ & Ordinal & D.4 \\
\hline & $\begin{array}{c}\text { Keputusan } \\
\text { menginap } \\
\text { berdasarkan } \\
\text { pemilihan } \\
\text { penyalur } \\
\text { pemesanan } \\
\text { kamar } \\
\text { (distributor) }\end{array}$ & & $\begin{array}{l}\text { - Kegaraman saluran } \\
\text { pemesanan kamar } \\
\text { (reservasi) seperti } \\
\text { seperti by phone, walk } \\
\text { in guest, travel } \\
\text { agent,dsb } \\
\text { - Kemudahan dalam } \\
\text { melakukan pemesanan } \\
\text { kamar (reservasi) }\end{array}$ & $\begin{array}{l}\text { - Tingkat keragaman } \\
\text { saluran pemesanan } \\
\text { kamar (reservasi) } \\
\text { seperti seperti by } \\
\text { phone, walk in guest, } \\
\text { travel agent, dsb } \\
\text { - Tingkat kemudahan } \\
\text { dalam melakukan } \\
\text { pemesanan kamar } \\
\text { (reservasi) }\end{array}$ & Ordinal & D.5 \\
\hline & & & $\begin{array}{l}\text { - Kestrategisan lokasi } \\
\text { dari Anggrek } \\
\text { Shopping Hotel } \\
\text { Bandung }\end{array}$ & $\begin{array}{l}\text { - Tingkat kestrategisan } \\
\text { lokasi dari Anggrek } \\
\text { Shopping Hotel } \\
\text { Bandung }\end{array}$ & Ordinal & D.7 \\
\hline & & & $\begin{array}{l}\text { - Aksesibilitas terhadap } \\
\text { lokasi Anggrek } \\
\text { Shopping Hotel } \\
\text { Bandung }\end{array}$ & $\begin{array}{l}\text { - Tingkat kemudahan } \\
\text { aksesibilitas terhadap } \\
\text { lokasi Anggrek } \\
\text { Shopping Hotel } \\
\end{array}$ & Ordinal & D.8 \\
\hline & $\begin{array}{l}\text { Keputusan } \\
\text { menginap } \\
\text { berdasarkan } \\
\text { waktu } \\
\text { menginap }\end{array}$ & & $\begin{array}{l}\text { - Menginap pada hari } \\
\text { biasa (weekday) } \\
\text { - Menginap saat libur } \\
\text { akhir pekan (weekend) }\end{array}$ & $\begin{array}{l}\text { - Tingkat intensitas } \\
\text { menginap saat hari } \\
\text { biasa (weekday) } \\
\text { - Tingkat intensitas } \\
\text { menginap saat akhir } \\
\text { pekan (weekend) }\end{array}$ & Ordinal & D. 10 \\
\hline & & & $\begin{array}{l}\text { Menginap saat libur } \\
\text { hari besar nasional }\end{array}$ & $\begin{array}{l}\text { Tingkat intensitas } \\
\text { menginap saat libur } \\
\text { hari besar nasional }\end{array}$ & Ordinal & D. 11 \\
\hline & & & $\begin{array}{l}\text { - Menginap berdasarkan } \\
\text { kebutuhan }\end{array}$ & $\begin{array}{l}\text { - Tingkat intensitas } \\
\text { menginap berdasarkan }\end{array}$ & Ordinal & D. 12 \\
\hline
\end{tabular}




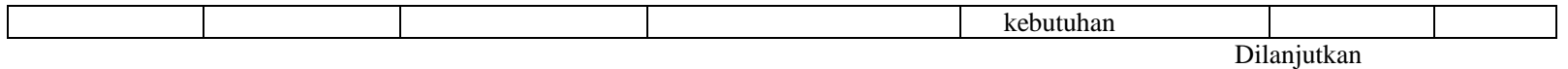

Lanjutan Tabel 3.1

\begin{tabular}{|c|c|c|c|c|c|c|}
\hline Variabel & $\begin{array}{c}\text { Sub } \\
\text { Variabel } \\
\end{array}$ & $\begin{array}{l}\text { Konsep Variabel } \\
\text { dan Sub Variabel }\end{array}$ & Indikator & Ukuran & Skala & $\begin{array}{l}\text { No } \\
\text { Item }\end{array}$ \\
\hline \multirow[t]{3}{*}{ (1) } & (2) & (3) & (4) & (5) & (6) & (7) \\
\hline & $\begin{array}{l}\text { Keputusan } \\
\text { menginap } \\
\text { berdasarkan } \\
\text { jumlah } \\
\text { pembelian } \\
\text { (jumlah } \\
\text { pemesanan } \\
\text { kamar) }\end{array}$ & & $\begin{array}{l}\text { - Frekuensi menginap di } \\
\text { Anggrek Shopping } \\
\text { Hotel Bandung } \\
\\
\text { - Lama menginap di } \\
\text { Anggrek Shopping } \\
\text { Hotel Bandung }\end{array}$ & $\begin{array}{l}\text { - Tingkat intensitas } \\
\text { tamu menginap di } \\
\text { Anggrek Shopping } \\
\text { Hotel Bandung } \\
\text { - Tingkat jangka waktu } \\
\text { tamu menginap di } \\
\text { Anggrek Shopping } \\
\text { Hotel Bandung }\end{array}$ & $\begin{array}{l}\text { Ordinal } \\
\text { Ordinal }\end{array}$ & D.13 \\
\hline & $\begin{array}{l}\text { Keputusan } \\
\text { menginap } \\
\text { berdasarkan } \\
\text { metode } \\
\text { pembayaran }\end{array}$ & & $\begin{array}{l}\text { - Keberagaman metode } \\
\text { pembayaran di } \\
\text { Anggrek Shopping } \\
\text { Hotel Bandung } \\
\text { - Kemudahan } \\
\text { melakukan } \\
\text { pembayaran di } \\
\text { Anggrek Shopping } \\
\text { Hotel Bandung }\end{array}$ & $\begin{array}{l}\text { - Tingkat keberagaman } \\
\text { metode pembayaran } \\
\text { di Anggrek Shopping } \\
\text { Hotel Bandung } \\
\text { - Tingkat kemudahan } \\
\text { melakukan } \\
\text { pembayaran di } \\
\text { Anggrek Shopping } \\
\text { Hotel Bandung }\end{array}$ & $\begin{array}{l}\text { Ordinal } \\
\text { Ordinal }\end{array}$ & D. 16 \\
\hline
\end{tabular}

\subsubsection{Metode Penarikan Sampel}

Sampel dalam penelitian ini yaitu tamu individu yang menginap di Anggrek Shopping Hotel Bandung. Jumlah sampel yang diambil dalam penelitian ini sebesar 100 sampel yang diambil dari jumlah populasi sebanyak 11.148 yang terdiri dari 3 kelompok, yaitu FIT (Free Individual Traveller) sebanyak 51 responden, WIG (Walk In Guest) sebanyak 16 responden, dan Travel Agent sebanyak 33 responden.

\subsubsection{Prosedur Pengumpulan Data}

Pengumpulan data yang dilakukan penulis menggunakan teknik sebagai berikut:

1. Studi kepustakaan

2. Observasi

3. Angket atau kuesioner

4. Wawancara

\subsection{Hasil Pengujian Validitas dan Reabilitas}

\subsubsection{Hasil Pengujian Validitas}

Berdasarkan hasil pengolahan data dengan menggunakan software komputer SPSS 17.0 menunjukkan bahwa item-item pertanyaan dalam kuesioner valid karena $\mathrm{r}_{\text {hitung }}$ lebih besar dari $\mathrm{r}_{\text {tabel }}$ yang bernilai 0.306 .

\subsubsection{Hasil Pengujian Reabilitas}

Hasil pengujian reabilitas product mix pricing strategyyang terdiri dari product line pricing, optional product pricing, dan product bundle pricing dengan keputusan menginap yang terdiri dari pemilihan produk, pemilihan merek, pemilihan penyalur, penentuan waktu menginap, jumlah pembelian (lama menginap) dan metode pembayaran. Pengujian tersebut menggunakan SPSS 17.0 model product moment (Peaeson) dapat dikatakan reliabel. Hal tersebut dikarenakan nilai reliabilitas untuk kedua variabel tersebut sebesar 0,795 dan 0,755 lebih besar dari bilai minimal yaitu 0,700 . 
TABEL 3.2

HASIL UJI RELIABILITAS INSTRUMEN PENELITIAN DENGAN C $\alpha$ MINIMAL 0,700

\begin{tabular}{|c|c|c|c|c|}
\hline $\begin{array}{c}\text { No } \\
\text { Variabel }\end{array}$ & Variabel & $\mathbf{C} \alpha_{\text {hitung }}$ & $\mathbf{C} \alpha_{\text {minimal }}$ & Keterangan \\
\hline 1. & Product Mix Pricing Strategy & 0,795 & 0,700 & Reliabel \\
\hline 2. & Keputusan Menginap & 0,755 & 0,700 & Reliabel \\
\hline
\end{tabular}

Sumber: Hasil Pengolahan Data, 2012.

\subsection{Pengujian Hipotesis}

Teknik analisis yang digunakan dalam penelitian ini adalah regresi linear berganda (multiple linear regression). Analisis regresi linear berganda adalah suatu alat analisis peramalan bagaimana keadaan (naik turunnya) variabel dependen (kriterium), bila dua atau lebih variabel independen sebagai faktor prediktor dimanipulasi (dinaik turunkan nilainya). Variabel yang dianalisis adalah variabel independen $(\mathrm{X})$ yaitu $(\mathrm{X} 1)$ product line pricing, (X2) optional product pricing, dan (X3) product bundle pricing, sedangkan untuk variabel dependennya (Y) yaitu keputusan menginap. Selanjutnya struktur hubungan diatas diterjemahkan kedalam hipotesis yang menyatakan pengaruh variabel bebas yang dominan terhadap variabel terikat. Untuk lebih jelas, dapat dilihat pada Gambar 3 berikut:

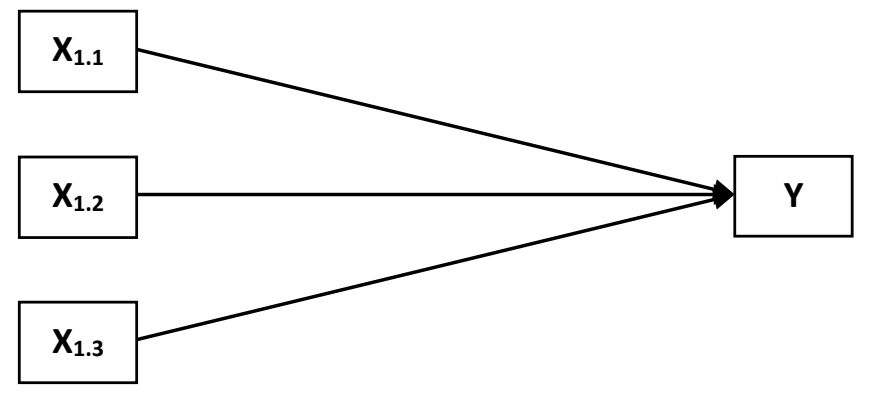

GAMBAR 3

REGRESI BERGANDA

\section{HASIL PENELITIAN DAN PEMBAHASAN}

\subsection{Gambaran Product Mix Pricing Strategy}

Tanggapan responden dari ketiga dimensi yang terdapat pada product line pricing, optional product pricing dan product bundle pricing yang tertinggi adalah product bundle pricing dengan rata-rata skor sebesar 325. Hal tersebut dikarenakan paket produk yang ditawarkan oleh pihak Anggrek Shopping Hotel Bandung dinilai sangat menarik perhatian para tamu dan memiliki keuntungan tersendiri bagi tamu yang membeli produk paket tersebut. Dengan mengeluarkan uang untuk satu produk pembelian, tamu mendapatkan value dua kali lipat dari biasanya.

Tanggapan terendah dari responden adalah product line pricing dengan rata-rata total skor sebesar 297. Hal tersebut disebabkan karena perbandingan harga antara Anggrek Shopping Hotel Bandung dengan pesaing sejenis yang memiliki klasifikasi bintang lebih tinggi dari Anggrek Shopping Hotel Bandung sangat jauh berbeda, responden beranggapan kekurangsepadanan jika harus membandingkan harga kamar hotel berbintang dua dengan hotel berbintang lebih tinggi meskipun memiliki jenis konsep hotel yang sama. 


\subsection{Gambaran Keputusan Menginap}

Tanggapan responden dari keenam indikator keputusan menginap yang terdiri dari pemilihan produk dan jasa, pemilihan merek, pemilihan penyalur, penentuan waktu menginap, jumlah pembelian (lama menginap), dan metode pembayaran yang memiliki penilaian tertinggi adalah pemilihan produk dan jasa dengan perolehan skor sebesar 400. Tingginya indikator pemilihan produk dan jasa dikarenakan produk dan jasa yang terdapat pada shopping hotel sangatlah menarik, karena mempunyai akses yang sangat dekat, mudah serta mempunyai koneksi langsung dengan pusat perbelanjaan (shopping mall), dan strategis dengan pusat perbelanjaan lainnya seperti factory outlet dan distro sehingga dapat memudahkan kegiatan berbelanja para tamu yang menginap di hotel yang berkonsep shopping hotel tersebut.

Tanggapan responden yang memiliki penilaian terendah terdapat pada indikator jumlah pembelian (lama penginap) dengan skor 282. Hal ini terjadi karena tamu individu yang menginap di Anggrek Shopping Hotel Bandung rata-rata menginap satu sampai tiga malam dalam sekali pemesanan kamar, dikarenakan mayoritas tamu yang menginap di Anggrek Shopping Hotel Bandung berasal dari daerah Jakarta dan mempunyai tujuan datang ke Bandung untuk berbelanja dan berwisata.

\subsection{Pengaruh Product Mix Pricing Strategy} Terhadap Keputusan Menginap di Anggrek Shopping Hotel Bandung

Pengujian hipotesis ditujukan untuk menguji pengaruh product mix pricing strategy terhadap keputusan menginap di
Anggrek Shopping Hotel Bandung. Secara simultan product mix pricing strategy mempunyai pengaruh terhadap keputusan menginap, karena $\mathrm{F}_{\text {hitung }}$ lebih besar dari $\mathrm{F}_{\text {tabel }}$ dengan skor signifikansi dibawah 0,10 . Hasil pengujian secara signifikan (Uji F) dapat dilihat pada Tabel 4.1 berikut:

TABEL 4.1

OUTPUT ANOVA

UJI SIGNIFIKANSI (UJI F)

DENGAN PERBANDINGAN $\mathrm{F}_{\text {Tabel }}=$

2.142

\begin{tabular}{|l|r|r|r|r|r|}
\hline Model & $\begin{array}{c}\text { Sum of } \\
\text { Squares }\end{array}$ & df & $\begin{array}{c}\text { Mean } \\
\text { Squar } \\
\text { e }\end{array}$ & F & Sig. \\
\hline 1 & 185.235 & 3 & 61.74 & 2.21 & .000 \\
Regressio & 2682.55 & 9 & 5 & 0 & a \\
$\mathrm{n}$ & 6 & 6 & 27.94 & & \\
Residual & 2867.79 & 9 & 3 & & \\
Total & 2 & 9 & & \\
\hline \multicolumn{5}{c}{ Sumber: Hasil Pengolahan Data, 2012 } \\
a. Predictors: (Constant), Product Line \\
Pricing, Optional Product Pricing, Product \\
Bundle \\
b. Dependent Cariable: Keputusan
\end{tabular}

Menginap

Pengujian secara parsial bertujuan untuk melihat pengaruh antara masingmasing variabel independent mempengaruhi variabel dependent signifikan atau tidak dan untuk memberi informasi dari keseluruhan variabel bebas yaitu product mix pricing strategy, variabel mana yang pengaruhnya paling dominan atau paling besar. Tabel 4.2 memperlihatkan secara lengkap berdasarkan hasil statistik hasil pengolahan data pengaruh product mix pricing strategy beserta ketiga sub variabelnya terhadap keputusan menginap di Anggrek Shopping Hotel Bandung.

TABEL 4.2

OUTPUT KOEFISIEN REGRESI PRODUCT MIX PRICING STRATEGY TERHADAP KEPUTUSAN MENGINAP DI ANGGREK SHOPPING HOTEL BANDUNG DENGAN PERBANDINGAN $\mathrm{t}_{\text {Tabel }}=\mathbf{1 , 6 6 1}$

Coefficients $^{\mathrm{a}}$

\begin{tabular}{|c|c|c|c|c|c|}
\hline \multirow[t]{2}{*}{ Model } & \multicolumn{2}{|c|}{$\begin{array}{l}\text { Unstandardized } \\
\text { Coefficients }\end{array}$} & \multirow{2}{*}{$\begin{array}{c}\text { Standardized } \\
\text { Coefficients }\end{array}$} & \multirow[b]{2}{*}{$\mathrm{t}$} & \multirow[b]{2}{*}{ Sig. } \\
\hline & $\mathrm{B}$ & Std. Error & & & \\
\hline 1 (Constant) & 42.065 & 1.662 & & 11.488 & .000 \\
\hline product line pricing & .629 & .445 & .179 & 2.415 & .060 \\
\hline
\end{tabular}




\begin{tabular}{|l|r|r|r|r|r|}
\hline optional product pricing & .509 & .222 & .297 & 2.299 & .012 \\
product bundle pricing & .123 & .358 & .024 & 2.188 & .052 \\
\hline
\end{tabular}

Sumber: Hasil Pengolahan Data, 2012

a. Dependent Variable: Keputusan Menginap

V. KESIMPULAN

Secara parsial semua variabel bebas (product mix pricing stategy) mempunyai pengaruh yang signifikan terhadap variabel terikat (keputusan menginap), karena $t_{\text {hitung }}$ dari ketiga sub variabel product mix pricing strategy lebih besar dari $\mathrm{t}_{\text {tabel }}$ yaitu 1,661 dengan nilai signifikan dibawah 0,1 . Hal ini berarti hipotesis yang diajukan diterima semua.

Langkah berikutnya adalah menentukan skor koefisien korelasi dan skor pengaruh antara product mix pricing strategy terhadap keputusan menginap yang dapat dilihat pada Tabel 4.3 berikut:

TABEL 4.3

OUTPUT PENGARUH PRODUCT MIX PRICING STRATEGY TERHADAP KEPUTUSAN MENGINAP DI ANGGREK SHOPPING HOTEL BANDUNG

Model Summary ${ }^{b}$

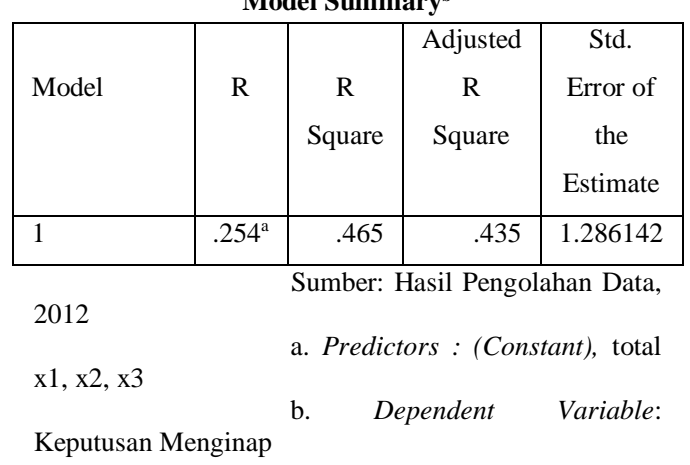

Berdasarkan Tabel 4.3 diperoleh skor koefisien korelasi product mix pricing strategy dengan keputusan menginap yaitu sebesar 0,465. Bila interpretasi pada tabel korelasi, maka hubungan antara product mix pricing (X) dengan keputusan menginap (Y) memiliki hubungan yang cukup kuat sesuai dengan klasifikasi koefisien korelasi. Besarnya pengaruh product mix pricing (X) terhadap keputusan menginap (Y) adalah sebesar $46,5 \%$, sedangkan sisanya sebesar $53,5 \%$ dipengaruhi oleh faktor lain yang tidak diikutsertakan dalam penelitian ini.

Berdasarkan kajian teori, hasil penelitian dan pengujian regresi berganda yang dilaksanakan mengenai pengaruh product mix pricing strategy terhadap keputusan menginap di Anggrek Shopping Hotel Bandung, dapat disimpulkan sebagai berikut:

1. Gambaran mengenai product mix pricing di Anggrek Shopping Hotel Bandung secara umum mendapat penilaian yang cukup tinggi dari tamu individu yang menginap di Anggrek Shopping Hotel Bandung. Cukup tinggi disini berarti harga yang ditawarkan oleh Anggrek Shopping Hotel Bandung terbilang cukup mahal. Penilaian tertinggi diperoleh oleh product bundle pricing, sedangkan penilaian terendah diperoleh oleh product line pricing. Hal tersebut dikarenakan harga produk yang ditawarkan oleh Anggrek Shopping Hotel Bandung dengan pesaing sejenis yang memiliki klasifikasi bintang lebih tinggi dari Anggrek Shopping Hotel Bandung sangat jauh berbeda. Hal ini membuat para responden merasa kekurangsepadanan jika harga produk yang terdapat di hotel bintang dua seperti Anggrek Shopping Hotel Bandung harus membandingkan harga produknya dengan harga produk yang ditawarkan di hotel dengan klasifikasi hotel bintang tiga keatas sekalipun itu hotel yang mempunyai konsep yang sama, yaitu shopping hotel.

2. Gambaran mengenai tingkat keputusan menginap di Anggrek Shopping Hotel Bandung mendapat penilaian yang tinggi. Tinggi disini berarti tingginya minat tamu untuk menginap di Anggrek Shopping Hotel Bandung karena alasan tempatnya yang strategis dengan pusat perbelanjaan seperti Riau Junction, factory outlet dan distro yang tersebar di sekitar Anggrek Shopping Hotel membuat tamu tertarik untuk 
menginap di Anggrek Shopping Hotel Bandung. Penilaian tertinggi diantara keenam sub variabel keputusan menginap adalah keputusan menginap berdasarkan pemilihan produk dan jasa yang ditawarkan di shopping hotel yang tersebar di Kota Bandung, khususnya produk dan jasa yang ditawarkan oleh Anggrek Shopping Hotel Bandung. Penilaian terendah dari sub variabel keputusan menginap disini terdapat pada jumlah pembelian (jumlah pemesanan kamar).

3. Product mix pricing strategy yang terdiri dari product line pricing, optional product pricing, dan product bundle pricing memiliki pengaruh yang signifikan terhadap keputusan menginap yang terdiri dari pemilihan produk dan jasa, pemilihan merek, pemilihan penyalur atau distributor, jumlah pemesanan kamar, pemilihan waktu menginap dan metode pembayaran di Anggrek Shopping Hotel Bandung dengan tingkat pengaruh cukup tinggi.

\section{DAFTAR PUSTAKA}

\section{BUKU dan $E$-BOOK}

Baker, Michael. 2012. E-book The Marketing Book. 5th Edition. Genesis Typesetting. Great Britain

Boone, E Louis and Kurtz, David L. 2012. E-book Contemporary Marketing 2013. South Western Cengage Learning. USA

Daft, Richard L. 2012. E-book Management. 10th Edition. Vanderblit Univercity. USA

Data Marketing Anggrek Shopping Hotel Bandung. 2012. LL.RE Martadinata: Bandung

Data Marketing Aston Braga Service Apartement Bandung. 2012. Braga: Bandung

Data Marketing Hyatt Regency Hotel Bandung. 2012. Sumatera: Bandung
Data Marketing Sensa Hotel. 2012. Cihampelas: Bandung

Dinas Kebudayaan dan Pariwisata Kota Bandung. 2011. Bandung

Ebert, Ronald J and Griffin, Ricky W. 2008. Business Essentials. McGraw-Hill Irwin. New York

Fandy Tjiptono Gregorius Candra dan Dedi Adriana. 2008. Pemasaran Srtatejik. Yogyakarta

Husein Umar. 2007. Metode Riset Bisnis. PT. Gramedia Pustaka Utama. Jakarta

Kotler, Philip and Amstrong, Gary. 2012. Ebook Principle of Marketing. 14th Edition. Pearson Education Inc. New Jersey

Kotler, Philip and Keller, Kevin Lane. 2012. E-book Marketng Management. 14th Edition. Pearson Education Inc. New Jersey

Pride, William M and Ferrell, O.C. 2012. Ebook Foundation of Marketing. 5th Edition. Texas A\&M. Texas

Pride, William M; Hughes, Robert. J and Kapoor, Jack. R. 2012. Foundations of Business. 3th Edition. South Western Cengage Learning. USA

Schiffman, Leon G and Kanuk, Leslie Lazar. 2012. E-book Customer Behaviour: A European Outlook. 2nd Edition. Pearson Education Inc. New Jersey

Spillane, James Josep S.Y, 2009. Ekonomi Pariwisata: Sejarah dan Prospeknya. Kanisius, Yogyakarta

Suharsimi Arikunto. 2009. Prosedur Penelitian Suatu Pendekatan Praktis. Yogyakarta: Bina Aksara.

Sugiyono. 2010. Metode Penelitian Bisnis. Bandung: CV Alfabeta.

Sugiyono. 2011. Metode Penelitian Bisnis. Bandung: CV Alfabeta.

Ulber Silalahi. 2009. Metode Penelitian Sosial. PT. Refika Aditama. Bandung

Undang-Undang Republik Indonesia Nomor 10 Tahun 2009 Tentang 
Kepariwisataan. Jakarta, Indonesia.

\section{WEBSITE dan JURNAL}

Data Kunjungan ke Situs Resmi Pariwisata Indonesia. 2011. Google Analytics. Melalui www.google.com. Diakses pada 14 Februari 2012 pukul 19.20

Data Tingkat Penghunian Kamar di Jawa Barat. 2012. Google Analytics. Melalui www.google.com. Diakses pada 13 Oktober 2012 pukul 10.00

Definition of Management. 2008. Melalui www.managementstudyguide.co $\mathrm{m}$.

Diakses pada 16 Juni 2012 pukul 17.00

Fenomena Hotel di Indonesia. 2012. Melalui www.kompas.com. Diakses pada 13 Oktober 2012 pukul 09.20

Journal An Eximination of Factors That Affect Pricing Decisions for Export Market, 2005, Etienne Musonera, Mexico USA

Journal The Impact of Product Pricing on Cuustomers Buying Behaviour in Kalapet Hotel. 2012. Ganesh Dash, India.

Journal The Impact of Price Bundling and Travel Product Practices Used by Online Channels of Distribution to Customer Buyer Behaviour in hotel Industry. 2008. Jinhoo Kim and David C Bojanic. USA

Journal Competitive Product Mix Pricing Strategy Hotel to Purchase Decision in Uncertain Times. Cathy A. Enz, Linda Canina and Mark Lomanno. 2009. USA 